\title{
STATUTORY VALIDATION OF PUBLIC BONDS
}

\author{
Frank E. Horack, JR.* and C. Ben Dutton $†$
}

$\mathrm{E}$ VEN the state finds need for correcting past mistakes and validating past actions. The demands for meeting obligations fairly incurred, preserving credit, and guaranteeing responsible action bulk large wherever continuously satisfactory financial relations must be preserved. Thus, although judicial remedies are available to the holders of public bonds, ${ }^{x}$ the advantages of legislative validation ${ }^{2}$ have made pertinent the study of curative legislation as a device for the preservation of public credit and the assurance of responsible public financing.

Unfortunately, judicial analysis of this type of curative legislation has been but little developed. Generally, the curative act has been accorded two distinguishing characteristics. By definition it is retroactive. ${ }^{3}$ By nature it is special. ${ }^{4}$ Specific constitutional limitations have seldom been set against its use; but the curative statute must

* Professor of Law, Indiana University.

† Student Research Assistant, Indiana University School of Law.

× Common among the judicial remedies is recovery in quasi-contract, Nuveen \& Co. v. Quincy, II5 Fla. 5ro, I56 So. 153 (I934); Cook v. Staunton, 295 Ill. App. Ir I, I4 N.E. (2d) 696 (I938); Board of Com'rs v. McClellan, I64 La. 808, II4 So. 694 (I927). On occasion, the holder of an invalid bond has been considered a holder in due course, Caldwell v. Guardian

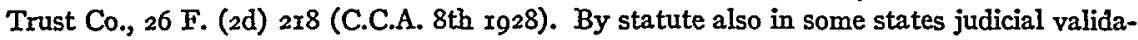
tion decrees are permitted, Humphreys v. State, Io8 Fla. 92, 145 So. $85^{8}$ (I933); Watts v. Cave Spring, I77 Ga. 808, I7 1 S.E. 382 (r933).

= The principal advantages are a non-litigious settlement of the controversy and consequent savings in court costs and attorney's fees; the removal of defects before controversy arises; formal recognition of the claim of bondholders; and a legislative direction to the municipality to make good its obligations.

3 The terms "retroactive" and "retrospective" are synonymous in judicial usage. It is true that in the sense that all legislation is passed to make improvements in law, all statutes are curative. The term "curative act," however, is restricted to acts which attempt to remedy defects arising prior to the date of their enactment and may be defined as statutes operating retroactively to obviate defects under existing law. See Smith, Retroactive Laws and Vested Rights, 5 Tex. L. Rev. 23 I (r927).

4 Most state constitutions contain restrictions on the passage of special laws. As a result, curative acts usually are couched in general language. Curative statutes are enacted to remedy particular defects, however, and irrespective of their form or phraseology are confined in application to the specific situations.

3 There are no state constitutions specifically prohibiting the passage of curative statutes. There are in some constitutions provisions against the passage of retrospective laws, e.g., Colorado, Georgia, Missouri, New Hampshire, Ohio, Tennessee, and Texas. These provisions 
meet the constitutional requirements demanded of all legislative enactment. ${ }^{6}$

The very enactment of curative legislation suggests the existence of past defective action of potentially injurious consequence. Thus, to consider the curative act independently of the circumstances which produced it creates inevitable confusion. The legality of the original statutory authorization, the character of the action taken under its mandate, and the subsequent validation, though comprising a single picture, must be analyzed separately.

The curative act may seek either to furnish authority retroactively for the issuance of bonds, or it may reach past the original statute and validate the bonds directly. If the original act is invalid, it cannot be validated for this would permit the indirect accomplishment of a prohibited result. A substituted valid authority, however, may be enacted retroactively.

In case the original authorizing statute was valid but was not complied with so that the bonds are procedurally defective a curative act may be passed sustaining the action which was in fact taken on the theory that this action might have been authorized originally. The result is the same in each situation; but in neither case should validation of the original legislative act be attempted. Safety dictates that validation should be directed toward the bonds and not toward authorizing legislation.

For example, a special act authorizing a bond issue would for its speciality be unconstitutional and that defect could not be cured by a subsequent validating act; yet because the bonds might have been validly issued under the authority of a general act, a curative act can operate di-

usually are construed to prohibit only the passage of retroactive statutes which violate other constitutional principles, the fact that a statute is retroactive not being of itself sufficient to invalidate it. See American States Water Service Co. v. Johnson, 88 P. (2d) 770 (Cal. I939); Bullard v. Holman, I84 Ga. 788, I93 S.E. 586 (I937); Stott v. Stott Realty Co., 288 Mich. 35, ${ }_{284}$ N.W. 635 (1939); Baker v. Rose, I65 Tenn. 543, 56 S.W. (2d) 732 (1933); Kelly v. Republic Bldg. \& Loan Ass'n, 34 S.W. (2d) 924 (Tex. Civ. App. r930).

${ }^{6}$ Thus a curative act may not violate due process of law by (I) divesting vested rights: United States v. Standard Oil Co. of California, 2x F. Supp. 645 (Cal. 1937); Sanger v. Bridgeport, I24 Conn. I83, I98 Atl. 746 (I938); Steger v. Traveling Men's Bldg. \& Loan Ass'n, 208 Ill. 236, 70 N.E. 236 (I904); Canovaro v. Brothers of Order of Hermits, 326 Pa. 76, Igr Atl. x40 (I937); or (2) validating jurisdictional defects: Park v. Modern Woodmen of America, I8I Ill. 214, 54 N.E. 932 (r899); Willis v. Hodson, 79 Md. 327, 29 Atl. 604 (I894); Dunkum v. Maceck Bldg. Co., 256 N.Y. 275, I76 N.E. 392 (r93I). A curative act may not violate obligation of contract: Watson v. Mercer, 33 U.S. 88 (I834); Sanger v. Bridgeport, I24 Conn. 183, r98 Atl. 746 (r938); In re Boalt, $x 23$ Ore. I, 260 Pac. 1004 (I927). Curative acts may be invalid for legislative interference with judicial powers: Sidway v. Lawson, 58 Ark. II7, 23 S.W. 648 (1893); Bagg's Appeal, 43 Pa. St. 5 I2 (1862). 
rectly upon the bonds and validate them in spite of the invalidity of the original authorizing statute.

Similarly, confusion must be avoided between decisions refusing to enforce payment on bonds and decisions invalidating the curative act as such. Several distinctions should be noted. The curative act may be declared unconstitutional because of procedural or substantive defects. Conversely, the statute may be valid as an act but the bonds or the procedure of their issuance may not be validated. Even if the curative act is valid, and the action of the issuing authority may thereby be validated, constitutional limitations may prevent the payment of the bonds. Each step in the chain of validity must be taken separately.

Inasmuch as the complications of bond validation cannot arise until the constitutionality of the curative act qua act is established, it is appropriate first to analyze the act itself.

\section{CONSTITUTIONAL RESTRICTIONS ON ENACTMENT}

As already indicated the curative act must comply with constitutional limitations applicable to all legislative enactments. Of particular concern in curative act litigation is the applicability of special legislation, the title, and subject matter limitations.

Curative acts passed to validate municipal bonds in most instances are, or appear to be, special in character. Where the original act is particular, courts may avoid declaring it special if they find that it has made a reasonable classification of the subject matter or find that no general law would be applicable. ${ }^{7}$ This imports validity to the original authorizing act and, thus, if there are no defects in the bonds themselves, a curative act is not necessary for there is no lack of original authority. If the procedure or formalities of the bond issue need validation, then a curative act in the same form as the original act will not offend the special legislation rule if

7 If there is a specific constitutional provision forbidding special legislation on a certain subject, the courts determine whether an act is special or general by testing the classification. Thus, if the classification is reasonable and not arbitrary or discriminatory, the act is upheld as a general act upon the subject matter.

If there is no specific constitutional prohibition against special legislation relating to this subject matter, the question turns on whether a general law is applicable or not. This issue can be evaded by holding that the judgment of the legislature is conclusive upon the applicability of a general law. However, in any event, if the law contains a reasonable classification, it is not special legislation but it is a compliance with the constitution, the enactment of a general law.

Reasonableness of classification has been said to be the proper test of a special statute in bond validation cases. Allegan v. Consumers' Power Co., 7 I F. (2d) 477 (C.C.A. 6th I934); Sambor v. Hadley, 29r Pa. 395, I40 Atl. 347 (I928); Kennedy v. Meyer, 259 Pa. 306, I03 Atl. 44 (I9r8). 
the court determines that the original act was valid. In this case the function of the curative act is to cure defects in administrative action rather than to cure a lack of original authority.

Even if the original act is special, a general curative act will validate bonds issued under the original invalid authority. ${ }^{8}$ The apparent result is an evasion of the constitutional prohibition against special legislation. This conclusion, however, grows from an imperfect understanding of the relationship between the original act, the action taken, and the curative act. Normally, the curative act does not purport to validate the special act. It only validates the bonds. Had the bonds been issued originally under a general act they would have been unimpeachable. The curative act only provides retroactively this original authority.

Legalistically, at least, this is no evasion for the special act is still invalid and the bonds are valid only because the new authority for their issuance was general. ${ }^{9}$ The defect in authority was procedural only. The legislature could have granted the authorization by general act. The declaration of unconstitutionality goes only to the manner in which the authority was granted and not to the legislative capacity to grant authority. Of course, if legislative authority was constitutionally prohibited, it could not be supplied by a curative act. ${ }^{10}$ Thus, assuming legislative power, the situation is the same as the case where bonds are issued without any statutory authority. The curative act in this case creates authority for the first time. The same is true where the first purported authority was invalid because of procedural defects in enactment. The curative act validates the bonds, not the original legislation. ${ }^{\text {Ix }}$

${ }^{8}$ Campbell v. Indianapolis, 155 Ind. I86, 57 N.E. 920 ( 1900 ).

9 Ibid. This result is in keeping with the general rule of curative acts which is that the legislature may validate any action it might previously have authorized. See Judith Basin land Co. v. Fergus County, 50 F. (2d) 792 (C.C.A. 9th I93I); Marr v. Southern California Gas Co., I98 Cal. 278, 245 Pac. 778 (I926); Bass v. Mayor, 30 Ga. 845 (I860); Duanesburgh v. Jenkins, 57 N.Y. I77 (I874); Appeal of Palmer, 307 Pa. 426, I6r Atl. 543 (I932).

so "If it [the legislature] is without constitutional power, it cannot, by a subsequent act cure the want of power to act in the first instance." Board of Education of Calloway County v. Talbott, 26r Ky. 66, 86 S.W. (2d) ro59 (I935).

II This distinction is made in Wight v. Police Jury of Avoyelles, La., 264 Fed. 705, 724 (C.C.A. $5^{\text {th }}$ Igr9): "It is, of course, impossible for the Legislature by a validating act, to accomplish that which it could not, on account of the limitation of the Constitution, have done primarily. But, within the terms of the Constitution, the Legislature had control of the manner in which the constitutional authority to levy taxes and issue bonds should be exercised..... As to the matters within control of the Legislature, no reason is seen why the validating act should not be given effect." See also Simpson v. Teftler, r76 Ark. I093, IIo7, 5 S.W. (2d) 350,355 (1928): "It [the legislature] could not do indirectly what the Constitution prohibits it from doing directly." 
Realistically, the act authorizing the bonds may be general, but because it is retroactive and the original invalid act was special the validating act will operate in and only in the situation created by the special act. Thus, the doctrine that the legislature cannot do indirectly what it cannot do directly seems to receive lip service only. This is not altogether indefensible, however, for there is no prospective operation of the act which is permitted, and retrospectively "the ratifying acts are entitled to much favor and respect .... if the effects thereof are in harmony with equity, justice, and public policy." ${ }^{2}$

Occasionally, it has been contended that a general validating act cannot have effect if prior to its enactment the authorizing act has been declared unconstitutional, as this would permit legislative interference with judicial functions and thus would violate the doctrine of the separation of powers. This contention cannot be sustained. The judicial determination of unconstitutionality is not disturbed by the legalizing act-indeed it is legislatively confirmed. The judicial decision, although making the bonds unenforceable, does not make them a nullity; consequently if a proper validating act is passed, the lack of original authority has been cured; the bonds become enforceable unless some other defect exists.

If in anticipation of litigation contesting the speciality of the authorizing act, the legislature passes a curative statute, its enactment is purely precautionary, for until there is a judicial decision holding the authorizing act to be special the presumption in favor of its constitutionality prevails and the bonds are enforceable under its terms. Not until the original act is judicially declared unconstitutional is a validating act necessary to provide new authority for the bonds.

The curative act frequently is opposed on the ground that it violates the constitutional restriction on dual subject matter. The allegation is that the statute retroactively attempts to achieve two objectives, i.e. (I) authority to issue the bonds, and (2) validation of the bonds originally issued. Usually this contention will not be sustained because of the liberal interpretation which courts give this constitutional provision. Although the means are multiple, the court will find the object or subject matter single. ${ }^{\mathrm{x}}$

The dual subject matter objection will be more effective, not against the validating act, but against the original authorizing act. But where the subject matter is dual, or has not been properly expressed in the title of the act, a curative act may make the bonds enforceable. The theory is

$x 2$ Campbell v. Indianapolis, 155 Ind. 186, 206, 57 N.E. 920, 927 (1900).

${ }^{33}$ See Richman v. Supervisors, 77 Iowa 513,42 N.W. 422 (1889). 
similar to that expressed in the case of special legislation. Inasmuch as the defects existing in the form of the bill or in its enactment are procedural only, the bonds but not the act can be validated. ${ }^{\mathrm{T}}$

\section{VALIDATION OF BONDS IN EXCESS OF DEBT LIMITATIONS}

Popular demand for public services has always run ahead of a willingness to pay for them. The apparent ease of shifting burdens to future generations has induced many communities to issue bonds far in excess of the dictates of sound fiscal management. As a consequence, statutory and constitutional restrictions against incurring debts beyond the ability to pay frequently have been imposed upon states and their political subdivisions..$^{x 5}$ In spite of this explicit policy, constitutional and statutory debt limitations are frequently circumvented with the acquiescence of legislative statutes and courts alike. The curative or legalizing act has been one of the most successful devices by which the evasion has been accomplished.

Two conflicting policies produce the anomalous result that non-defective bonds ${ }^{\mathrm{x}}$ issued in excess of constitutional debt limits cannot be paid, but defective bonds ${ }^{17}$ in excess of the debt limit can be validated and paid under most circumstances. The policy against incurring excessive obligations conflicts with the policy of validating defective action wherever the credit of the state and fairness to bona fide holders demands validation. In the case of such conflict the latter policy. usually prevails with the anomalous result indicated.

\section{A. CONSTITUTIONAI DEBT LIMITS AND NON-DEFECTIVE BONDS}

Where bonds are issued without procedural or instrumental defects under procedurally valid authorizing statutes but the issuance is in excess of a constitutional debt limitation, no legislative or judicial machinery is

${ }_{44}$ Kennedy v. Meyer, 259 Pa. 306, ro3 AtI. 44 (rgr8).

x5 It is not within the scope of this article to investigate the effect of a statutory debt limit. Statutory debt limits should not cause any great difficulty, however, since a curative act passed to validate bonds issued in excess of the statutory limit would operate as an implied repeal of the limitation. A statutory debt limit is subject to change by the legislature. State v. Board of Education of Topeka, I37 Kan. 45I, 21 P. (2d) 295 (I933).

${ }^{16}$ As used in this section the phrase "non-defective bonds" means that the bonds were issued by proper authority, under a valid statute, and are not procedurally or instrumentally defective. As here defined, "non-defective bonds" may be unenforceable because they exceed a constitutional debt limit.

I7 "Defective bonds" as here defined are bonds issued without statutory authority, under an invalid authorizing statute, or which are procedurally or instrumentally defective. 
available to enforce payment of the bonds. ${ }^{18}$ When situations of this character have arisen the courts have consistently enforced the debt limitation and have refused to permit payment when it is contested. ${ }^{x}$

\section{B. CONSTITUTIONAL DEBT IIMTTS AND DEFECTIVE BONDS}

Although in no situation may payment be enforced on a non-defective bond issued in excess of a debt limitation, in three out of four possible situations where defective bonds are issued in excess of debt limitations payment may be enforced:

I. Where no debt limit exists at time of issuance or the debt limit has not been exceeded at the time of issuance but a debt limit has been imposed or will be exceeded at the time of the attempted validation, validation is permitted.

2. Where the debt limit would have been exceeded by non-defective bonds at the date of issuance but is not exceeded at the date of attempted validation by validated bonds, validation is permitted.

3. Where the debt limit is not exceeded at the date of issuance or at the date of attempted validation although it may have been exceeded in the interim, validation is permitted.

4. Only in case the debt limitation is exceeded both at the date of issuance and at the date of attempted validation is validation denied.

Apparently, the cause of the invalidity of the bond does not alter the result in any of these four situations. Thus wherever there is a valid curative act, the result will be the same in each case although (I) the authorizing act was valid but the bonds were defectively issued, (2) the authorizing act was invalid or there was no authorizing act and the bond itself was not defective, and (3) the authorizing act was invalid or non-existent and the bond was defective.

This anomaly - the circumvention of a constitutional debt limit-has been accomplished by the application of two different theories so that whenever either theory or both theories support the validation of the bond, the bond will be sustained.

The $a b$ initio rule.-Wherever defectively issued bonds do not exceed the debt limitation at the time of issuance, or no debt limit exists at time of issuance courts will sustain a curative act which purports to cure defects in issuance arising either from a lack of, or invalid, statutory authority,

${ }^{18}$ That is, there is no legislative or judicial machinery available to permit recovery on the bonds themselves as valid enforceable obligations. That there might be recovery in quasicontract, etc., is not denied.

s9 See notes ro and Ix supra. 
improper issuing procedure, or instrumental defects in the bond. ${ }^{20}$ The reason advanced for the validation of these bonds, even though at the time of validation the debt limitation has been reached and the validation will result in exceeding the limitation, is that the legislature could have passed a valid act at the time of original enactment or could have provided by statute for the procedure actually followed in the issuance of the bonds. Thus in the leading case, Schneck v. City of Jeffersonville, ${ }^{2 x}$ the court said:

[The] effect and operation [of] the act must be held equivalent to conferring original legislative authority upon the City of Jeffersonville which would have authorized it to incur the indebtedness and issue the bonds to obtain the necessary means to defray the debt; and these obligations must therefore be considered in the same light as though they were valid ab initio. .... Such ratifying or legalizing act of the legislature, .... is of the nature, or, rather, analogous to, a ratification by the principal of the unauthorized acts of the person who assumed to be his agent.

The apparent desires of municipalities, bondholders, and courts coincide to raise a presumption in favor of validity wherever possible and thus the anomalous rule of ratification which has so frequently caused distress to the logic of the law of agency is incorporated into the law of legalizing acts to give not only a retroactive validation but an ab initio validation to unauthorized or defective action..$^{22}$ The result is that the constitutional debt limitation imposed upon a municipality becomes almost meaningless. If at the time the bond was defectively issued the constitutional debt limit had not been reached or no constitutional debt limit existed, the bonds may be validated although at the time of validation the city had outstanding bonds in excess of the debt limit in reliance upon the invalidity of the contested issue. ${ }^{23}$

${ }^{20}$ Lack of statutory authority: Schneck v. Jeffersonville, I $_{2}$ Ind. 204, 52 N.E. 2 I2 (I898); People v. Mitchell, 35 N.Y. 55I (1866). Invalid statutory authority: Campbell v. Indianapolis, I55 Ind. 186, 57 N.E. 920 (I900); Kennedy v. Meyer, 259 Pa. 306, 103 Atl. 44 (I9r8). Improper issuing procedure and instrumental defects in the bonds: Thomson v. Lee County, 3 Wall. (U.S.) 327 (I865); Marr v. Southern California Gas Co., I98 Cal. 278, 245 Pac. 178 (I926); Clinton v. Walliker, 98 Iowa 655,68 N.W. 43 I (1896); Duanesburgh v. Jenkins, 57 N.Y. $177(1874)$.

${ }^{2 x}{ }_{52}$ Ind. 204, 2I6, 2I7, 52 N.E. 2I2, 216 (1898).

"See Wambaugh, A Problem as to Ratification, 9 Harv. L. Rev. 60, 6r (I895). "Unquestionably ratification and original authorization are similar; and unquestionably ratification, unless some rule prevents it from having efficacy, relates back, and is thereupon substantially equivalent to original authorization. Yet there are many instances where ratification is wholly inefficacious, where relation does not take place, and where ratification and original authorization turn out to be very different things indeed."

${ }^{23}$ Thomson v. Lee County, 3 Wall. (U.S.) 327 (I865); Schneck v. Jeffersonville, I52 Ind. 204, 52 N.E. 212 ( 1898 ). It must be noted that the municipality cannot prevent validation of the bonds.by any claim of "injurious reliance" on the invalidity of its own bonds. The moral obligation to repay purchasers is too strong to permit such a defense. Issuance of new 
The present ability rule.-If the ab initio theory were followed consistently, whenever the defective issue exceeded the debt limitation at the time of issuance the bonds would be unenforceable just as valid bonds are unenforceable. The validation would operate from the date of the issuance of the bonds and as at that date the bonds could not validly be issued because of the constitutional limitation, no legalizing act could grant authority to exceed the debt limit. ${ }^{24}$ This would be consistent with the rule that a curative act can only legalize those things which might have been authorized at the date of original action. ${ }^{25}$ However, the desire to preserve municipal credit and to save "innocent" bondholders indicates the desirability of another principle which we shall call "The Present Ability Rule." According to this principle if the debt limitation is not exceeded at the date of validation, the validation is proper even though the limit would have been exceeded at a prior date, because the validation operates from the date of the enactment of the curative statute.

This result must be made without the assistance of any judicial decision directly on the point. ${ }^{26}$ The presumption of validity is founded upon the general desire of courts to give remedial legislation a liberal interpretation, ${ }^{27}$ to preserve so far as possible municipal credit ${ }^{28}$ and to protect purchasers for value. ${ }^{29}$ Negatively, the fictional character of ab initio validation argues strongly against its application in a manner which will require

bonds in reliance on the invalidity of the prior issue as used here, means only that municipal officers, thinking the claims of bondholders unenforceable, have embarked the municipality upon new borrowings.

${ }^{24}$ Forbes Pioneer Boat Line v. Board of Com'rs of Everglades Drainage Dist., 258 U.S. 338 (1922); Board of Education of Calloway County v. Talbott, 26I Ky. 66, 86 S.W. (2d) ro59 (1935).

25 See note 9 supra.

${ }^{26}$ Although it seems probable that there have been curative acts cases reaching the result sought by the "present ability rule," none has been found. In view of the modern tendency to abandon legal fictions whenever possible, the recommendation of the "present ability theory" is not a radical nor an illogical step.

${ }^{27}$ Remedial statutes are to be liberally construed. 2 Sutherland, Statutory Construction (Lewis' ed. I904) $\$ \$ 583-4$.

${ }^{28}$ Corliss, J., in dissenting from a decision holding county debt warrants validated, expresses this desire. ". . . I wish to express my pleasure that the majority of this court are able to reach a conclusion contrary to this opinion, and hold the county liable on these warrants. To a new state, its financial honor is of the highest importance. To develop its resources, capital is indispensable, and every thing that savors of repudiation, in any form, tends to frighten capital from its borders." Erskine v. Nelson County, 4 N.D. 66, 9r, 58 N.W. 348, 357 (I893).

29 Great protection is accorded to bona fide purchasers and holders in due course. Statements that the bona fide purchaser is a "favorite of the law," etc., are common. See for example Scott v. Wilkinson, 215 Ala. 235, Iro So. 34 (1926). 
invalidity and destroy credit and injure bondholders. In short, the ab initio rule was developed and will be used to sustain, but not to invalidate, defectively issued bonds. ${ }^{30}$

It has already been pointed out that it is the issuance of the bonds, not the enactment of a statute, which is invalid if the debt limit is exceeded. Thus if an original act were passed and bonds issued at a time when the limit would not be exceeded the issue would be valid. Consequently it is argued that if a defective issue is validated as of such a time, the bonds are validated and the obligations are enforceable.

The logical difficulty which presents itself is that if the bonds were not defectively issued and exceeded the constitutional debt limit at date of issue, they cannot be validated, yet if the bonds were defectively issued, they can be validated and in many cases the effect of the debt limitation avoided. It would seem that if validation is permitted in the latter case, it should also be possible in the former, for when a bond is validated, it becomes non-defective. The only available distinction seems to be that although the two cases are similar in substance there is a procedural remedy available in the case of a defective bond but no remedy is available in the case of a non-defective bond. ${ }^{3 x}$

Situations where both theories apply. - Where the debt limit was not exceeded at the date of issuance or at the date of validation no problem is presented by the particular issue of bonds involved, even though it may be that in the interim between issuance and validation other bonds have been issued and the debt limit temporarily was exceeded on the belief that the first issue was invalid. If the question is raised, as it has been on a few occasions, ${ }^{32}$ either the ab initio theory will sustain the validity of the bonds because the debt limit was not exceeded at the time of issuance, or the present ability theory will sustain the bonds because if a new issue had been authorized at the time of validation, or if non-defective bonds had been issued at that date, there would be no doubt of validity.

Situations where neither theory will validate the bonds. - When validation of bonds would result in exceeding the debt limit both at the time of issu-

${ }^{30}$ Wambaugh, in commenting on agency decisions in which the theory of ab initio ratification is departed from, states: "In short, these supplemental rules indicate that the enforceability of the transaction really arises at the time of the ratification, and is incapable of arising then if absurd or unjust results would follow." Later in the same article the author continues: "This is one of the places where the law consciously takes cognizance of convenience and justice, and does not permit its usually convenient fictions to be carried too far." Wambaugh, A Problem as to Ratification, 9 Harv. L. Rev. 60, 62, 70 (1895).

${ }^{3}$ See note I8 supra.

${ }^{32}$ Bessemer Investment Co. v. Chester, 22 F. Supp. 3 II (Pa. I938). 
ance and at the time the validating act was passed, neither the ab initio theory nor the present ability theory will save the bonds. Inasmuch as the $a b$ initio theory cures bonds only when the debt limit was not exceeded at the date of issuance and the present ability theory is effective only when the debt limit is not exceeded at the date of validation, if the debt limit is exceeded at both dates the defective bonds may not be cured. Thus, only in this one situation would defective bonds be treated the same as valid bonds and the constitutional debt limitation be preserved against evasion. ${ }^{33}$

Partial validation by curative act.-Although defective bonds may be validated in every situation save one, there still remains the possibility of partially validating non-defective bonds and also defective bonds to the extent they do not exceed the debt limit.

Most decisions indicate that municipal indebtedness whether bonded or otherwise is not invalid except to the extent to which the constitutional limit is exceeded;34 thus, it would appear that curative acts would be appropriate to validate bonds within constitutional debt limits. The diffculty, of course, is in determining whether the limitation will be applied as of the date of the issuance of the bonds or as of the date of their validation and the procedure by which some bonds will be selected for validation and others excluded.

If validation is according to serial number, the selection seems to be purely arbitrary, for it assumes a difference in equities between the purchaser of the first bond and the purchaser of a bond of later serial number. ${ }^{35}$ Inasmuch as the first purchasers may often buy the entire series, the logic of the holding is doubtful although as a remedy for the bondholder it may be better than nothing at all.

Validation according to the order of date of sale likewise fails for similar reasons $;^{36}$ that is, first purchasers at least normally acquire the entire issue, and the date of sale to subsequent purchaser would seem to have no importance in determining the validity of the issue.

Certainly the fairest method is to apportion the loss between all the bonds and to "validate" the bonds on a pro rata basis. This obviates a possible objection raised to the first two procedures that there is a denial

33 Similarly, validation by judicial decree is denied when to validate the defective bonds would exceed the constitutional debt limit. State v. Belleair, I25 Fla. 669, I7o So. 434 (1936).

${ }^{4}$ Munroe v. Reeves, 7 I Fla. 6I2, 7I So. 922 (I9I6); Trepp v. Independent School Dist., 213 Iowa 944, 240 N.W. 247 (I932); Board of Com'rs v. McClellan, I64 La. 808, II4 So. 694 (I927).

35 Moreover, it is not likely that bonds always will be sold in exact serial number order.

${ }^{36}$ See Board of Com'rs v. McClellan, 164 La. 808, II4 So. 694 (I927). The case does not state that bonds of early serial numbers were first sold or give any other indicia by which to determine which bonds were sold first. 
of due process in that the procedure is arbitrary and discriminatory. Nevertheless, pro rata payment is hardly a validation of the bond but is more nearly a legislative attempt to permit recovery within its constitutional abilities.

Pro rata validation, however, has seldom been attempted..$^{37}$ Indeed, if the implications of the prior cases are correct, the only situation in which pro rata validation would be necessary would be in those limited situations where the original issuance of the bonds was non-defective or in those cases where defectively issued bonds exceed debt limits both at the time of issuance and at the date of validation.

If non-defective bonds exceed the debt limit and are therefore unenforceable, it may be argued that a curative act would be available to permit pro rata payment. This, of course, requires a new interpretation of what constitutes invalidity for purposes of curative act legislation. It does not seem, however, that the situation of a non-defective bond is essentially different from that of the defective bond; thus it would not be difficult for a court to hold that debt limit excess was a defect in validating the bonds so that a curative act would operate.

If this analysis is proper, then the only question which remains is whether the non-defective issue can be validated pro rata as of the date of issuance or as of the date of validation. Although it might appear that validation could be made only as of the date of issuance and the cases refusing to enforce the payment of non-defective bonds direct this conclusion, it would seem entirely appropriate for the court to select the date of validation. A curative act directing payment of the non-defective bond which exceeded the debt limit at time of issuance but did not exceed the debt limit at time of validation would merely be a direction restraining the legislature from issuing more bonds until the non-defective bonds were paid. In short, this is a legislative determination of priorities which requires the city to pay its existing issued bonds before it can incur new indebtedness. To require the city to meet its obligations, though invalidated because in excess of the debt limit before contracting new ones, would protect innocent purchasers, would preserve the credit of the city and, therefore, appeals to ethical standards of business management without, in fact, destroying the effectiveness of the debt limit.

This analysis would permit the legislature to enforce the debt limitation and still protect the bondholder; it would be impossible for the legislature to evade the debt limit by validating all bonds; it would make purchasers

${ }^{37}$ Indeed, the only case found in which a curative act was allowed to effect partial validation was reversed upon appeal, Mitchell County v. City Nat'l Bank, I5 Tex. Civ. App. 172, 39 S.W. 628 (1897), rev'd, 9I Tex. 36r, 43 S.W. 880 (r898). 
run the risk that bonds in excess of the debt limit would not be paid unless legislative action were taken; but it would permit the legislature, where the equities were strong, to restrain the city from incurring new obligations until it had paid those which in justice should be paid. The curative act as a device for the accomplishment of this result seems particularly appropriate. Pro rata validation likewise assists the flexibility of the rule, for by determining the date of validation the legislature can adjust the equities of the claim between bondholder and city within the limits of the due process clause.

\section{OBLIGATION OF CONTRACT}

Curative acts occasionally have been attacked as violating obligation of contract, but apparently there are no bond cases on the point. This is to be expected, however, for the curing of a particular series of bonds affirms the contract in those bonds, and the effect of validation on other issues is only indirectly disadvantageous. It is conceivable that bonds might be issued defectively in so large an amount that the validation of them might impair the security of other bonds. The real security, however, behind most municipal bonds is the general taxing power, and its impairment might be a violation, but an increased burden on the taxing power seems to be too remote. Thus, when the argument that the issuance of new bonds changed the value of bonds already issued was made to the Kansas Supreme Court, the court said: "it is purely speculative that it would have the effect contended." ${ }^{8}$ It is clear that bond validation statutes normally do not violate the obligations of contract.

\section{INTERFERENCE WITH JUDICIAI POWER}

The enactment of a curative statute after litigation has begun or after final judgment has been rendered, in most instances, is not unconstitutional.39 Although the statute results in an apparent impairment of the court's judgment, a majority of jurisdictions will hold that the separation of powers doctrine has not been violated.

At least in case the judgment goes to the validity of the authorizing statute, the curative act does not affect the judgment directly. The passage of the curative act reaffirms the judgment and provides a new authority in place of the invalidated authority. Consequently, the legislative activity is not inconsistent with or interfering with the judicial function,

${ }^{38}$ State v. Board of Education of Topeka, I37 Kan. 45I, 2I P. (2d) 295 (I933).

39 Curative acts may affect pending litigation, Clinton v. Walliker, 98 Iowa 655,68 N.W. 43 I (1896); Pyote Independent School District v. Dyer, 34 S.W. (2d) 578 (Tex Com'n of App. I93I). Contra: Columbus, C. \& I. C. R. Co. v. Board of Com'rs of Grant County, 65 Ind. 427 (1879). Curative acts may affect final judgments, King v. Course, 25 Ind. 202 (r865); Johnson v. Board of Com'rs of Wells County, ro7 Ind. I5, 8 N.E. I (I886); Richman v. Supervisors, 77 Iowa $5{ }^{1} 3,4^{2}$ N.W. 422 (1889). 
but rather after the court has invalidated one authority, the legislature provides a new authority with retroactive effect.

If the judgment has declared the bonds invalid for defective issuance, then a subsequent curative act affects the judgment directly. The curative statute even in this case need not go directly to the judgment, for while the legislature cannot annul it or set it aside it can remove defects upon which the judgment was rendered. ${ }^{40}$ Again, although legalistically this may satisfy a majority of jurisdictions that the doctrine of separation of powers is not violated, the actual effect is to permit a legislative reversal of the judgment. It helps but little to assert that the statute is "formative" rather than "judicial" in character. Basically this assertion affords a practical way for the court to provide formal compliance with constitutional requirements without too great an injury to creditors. Some statutes carry the parallelism further by specifically declaring that any payment shall be considered a gratuity. ${ }^{4 \mathrm{I}}$

Practically all the cases are in agreement that a curative act may render ineffective a judgment prior to the time that it becomes final..$^{42}$ Thus, the curative statute may be enacted at any time prior to appeal to the court of last resort. Apparently, the theory here is based more on the concept of vested rights than on separation of powers. Indeed, the interference with the judicial function is not different in either case so that if after judgment the legislative activity is bad, it would seem equally bad before the judgment became final.

The reasoning of the cases is that, although a direct overthrowal of a particular judgment would be unconstitutional, the legislature, subject to the usual constitutional limitations, may enact or amend a statute. Legislation having this effect does not "invalidate" judgments, but changes the law upon which future determinations may be made. It may be concluded, therefore, that curative statutes, unless directly attempting to overturn specific judgments, will successfully evade the apparent objection that the act constitutes an encroachment upon the judiciary.

${ }^{40}$ Thus in Johnson v. Board of Com'rs of Wells County, I07 Ind. I5, 8 N.E. I (I886), the court upheld the curative act though it expressly denied the power of the legislature to overturn judgments. Although not a case in which a judgment had been rendered prior to the enactment of the curative statute, the language of the court in Pyote Independent School Dist. v. Dyer, 34 S.W. (2d) 578 (Tex. Com'n of App. I93r) to the effect that "a curative statute ... . cures the defect the same as if such statute had become effective before the institution of the suit," would seem to direct the same result.

4I Of course payment is a "gratuity" only in the sense that it is not legally necessary to give the bond purchasers their money back. As recognized in the quasi-contract cases (note $I$ supra) there does in fact exist a strong "moral obligation" to refund the purchase price to the bondholders.

${ }^{42}$ See note 38 supra. 


\section{DUE PROCESS OF IAW}

Generally speaking, if a curative act escapes other constitutional pitfalls, it will not be declared in violation of the due process clause unless it impairs a "vested right." Professor Bryant Smith in his brilliant article pointed out that it might be assumed that " $\mathrm{A}$ right is vested when it is immune to destruction, and that it is not vested when it is liable to destruction, by retroactive legislation." It might be said as easily that a retroactive act is valid when it does not impair a "vested right" and that it is invalid when it does, but as Professor Smith suggests this does not advance much the analysis of due process and curative legislation.

In the bond cases the due process attack has usually been either (I) against the curative act on the ground that the act itself violates due process in attempting to validate defective rights or (2) against the bonds on the ground that they were issued in violation of due process and, thus, may not be validated by curative legislation.

It is argued in the first situation that although the acts done defectively did not in themselves constitute violations of due process, an attempt to change relationships between the parties results in the taking of property without due process. This, of course, proves too much, for many rights are divested under the police power and the illusive test of reasonableness is always available to support the validity of the action. The test of reasonableness as applied to bond cases normally will sustain the validating act for it usually results in the granting of a benefit rather than in the imposition of a harm. ${ }^{44}$ The presumption in favor of remedial legislation assists a determination in favor of the reasonableness of the legislative action. Thus, where the defect in the bond is procedural only or where the bond might be constitutionally issued without notice and hearing although the statutes in fact provide for it, failure to comply may be cured wherever the validation does not result in arbitrary discrimination between creditors or taxpayers.

The "vested rights" theory has been advanced to prevent a curative act affecting the course of pending litigation, but courts quickly determine that no "vested right" was created in pending litigation 45 and that final determinations must be governed by the law at the time the decision was

43 Smith, Retroactive Laws and Vested Rights, 5 Tex. L. Rev. 23I (I927), continued in 6 Tex. L. Rev. $4 \circ 9$ (r928).

14 Allegan v. Consumers' Power Co., 7 I F. (2d) 477 (C.C.A. 6th 1934); Judith Basin Land Co. v. Fergus County, 50 F. (2d) 792 (C.C.A. 9th I93r); Oregon Short Line R. Co. v. Clark County Highway District, 22 F. (2d) 68r (Idaho I927); Bass v. Mayor, 30 Ga. 845 (1860).

45 Duanesburgh v. Jenkins, 57 N.Y. I77 (1874). See also Mayor v. Wolcott, I2 Del. Ch. 379, II2 Atl. 703 (I92I); Worley v. Idleman, 285 Ill. 2I4, I20 N.E. 472 (I9I8); Houle v. Lussier, 50 R.I. 339, I47 Atl. $75^{6}$ (r929). 
rendered. When the curative act was passed after final judgment, some courts have held that the curative act does in fact impair "vested rights," ${ }_{46}$ but the better view does not extend due process protection even in this case unless the result of the curative act is unfair and unreasonable.

If the basis of attack is the invasion of due process not by the curative act but by the original act or by action taken under it, it is clear that a legalizing act would not cure the defect. Normally the case will not arise for the doctrine is established that lack of constitutional authority cannot be cured by legislative action. However, where the defect does not produce an injury, some courts are inclined to permit validation of constitutionally defective action but not of a lack of constitutional authority.

Since it is difficult to envisage a municipality claiming a "vested right" in the invalidity of its own bonds or asserting that it is deprived of due process by their validation, it is apparent that in most circumstances curative acts will escape the allegation of unconstitutionality on the ground that they violate due process.

Cases involving questions of procedural due process turn upon considerations of jurisdiction. Courts frequently have said that jurisdictional difficulties may not be validated, but this is not necessarily true in the bond cases. As pointed out in a recent Montana case ${ }^{47}$ the problem is solved by determining what body lacked jurisdiction. If the legislature had no jurisdiction, obviously the act cannot be sustained. On the other hand, if the lack of jurisdiction lies solely with the municipality, the defect can be legislatively remedied. If the legislature could have originally conferred jurisdiction on the municipality to issue bonds, it could have done so retroactively by a curative act.

Although the books contain numerous and frequently involved statements of the due process problem as it relates to the validity of curative legislation, it is apparent from the analysis of the results of these decisions that the due process objection will not invalidate legislation in those cases where the validation of the bond will protect the credit of the municipality, permit payment to the bondholders, and will not work serious discriminations among those who must pay. Perhaps more in these cases than in any others, the concept of due process of law is a concept of fairness and justice under the circumstances-a rule which may be tested by the circumstances of each case but which is unfortunately deficient in predicting future action with certainty.

${ }^{46}$ Such decisions usually have been in terms of legislative interference with judicial powers. See People v. Wiley, 289 Ill. I73, I24 N.E. 385 (x9xg); Mayor v. Horn, 26 Md. I94 (I866); Cowen v. State, ror Ohio 387 , r29 N.E. 719 (I920).

47 Weber v. Helena, 89 Mont. Iog, 297 Pac. 455 (193r). 